\title{
STRUKTUR HISTOLOGI HATI TIKUS PUTIH (Rattus norvegicus Berkenhout 1769) DENGAN PEMBERIAN RAMUAN TRADISIONAL MASYARAKAT MELAYU LINGGA, KEPULAUAN RIAU
}

\author{
Fitmawati*, Titrawani, Welly Safitri \\ Jurusan Biologi Fakultas Matematika dan Ilmu Pengetahuan Alam, Universitas Riau \\ Corresponding author: fitmawati2008@yahoo.com
}

\begin{abstract}
Lingga Island is the center of the Malay kingdom of Kepulauan Riau Province with local wisdom that is still ingrained in the community. Obat pahit is a decoction of linguistic stew of ethnic lingga community which is believed to be a youthful remedy and maintain stamina. This study aims to find histopathologic changes of liver white mice after the decoction of herb concoction of Obat pahit. The percentage of intercellular damage was nonexistent from the normal control group and positive control but different from the negative control group. Different types of medicinal herbs with different dosage levels. But the damage is still in the normal, accessible category that has no toxic effects from bitter herbs on liver organ.
\end{abstract}

Keywords: Histhology, liver, Obat pahit, white rat (Rattus norvegicus)

\section{PENDAHULUAN}

Penggunaan obat-obatan alami atau tradsional berasal dari tumbuhan terus mengalami perkembangan. Pemanfaatan tumbuhan berkhasiat obat telah lama dilakukan oleh masyarakat (Marianne et al., 2016). Salah satu daerah yang masih melestarikan tradisi pengobatan tradisional adalah Pulau Lingga. Pulau Lingga dulunya merupakan pusat kerajaan Melayu. Pulau Lingga terletak di Provinsi Kepulauan Riau yang terdiri dari 9 kecamatan, 7 kelurahan dan 74 desa. Beberapa desa masih menggunakan pengobatan tradisional yang dipercaya sebagai ramuan awet muda dan penjaga stamina yaitu Desa Kalan (8 jenis), Desa SP4 (25 Jenis) dan Desa Linau (16 Jenis) diantaranya akar pasak bumi, akar mengkudu, akar sebaju, cengkeh, temulawak dan lain-lain (Fitmawati et al., 2017). Setelah mengkonsumsi ramuan obat pahit dalam waktu lama masyarakat Melayu Lingga merasa kesehatannya terpelihara, hal ini diduga adanya khasiat dari ramuan obat pahit.

Masyarakat Melayu Lingga biasanya mengkonsumsi air rebusan ramuan obat pahit dengan meminum secara langsung. Penggunaan obat tradisional dengan cara diminum akan melalui proses pencernaan yang melibatkan penyerapan oleh usus. Usus sebagai saluran pencernaan menyuplai darah ke hati sehingga makanan dan minuman yang dikonsumsi suatu individu berkaitan erat dengan histologi hati.

Hati merupakan kelenjar tambahan dari saluran cerna yang terletak di kuadran kanan atas dari rongga abdomen, permukaan atas membulat sesuai dengan kubah diaphragm. Hati memiliki peranan penting karena berfungsi sebagai pembentukan dan sekresi empedu (Ozougwu, 2017). Hati juga berfungsi sebagai metabolisme nutrient dan vitamin yang diserap dari saluran pencernaan, selanjutnya akan dipakai oleh bagian tubuh lainnya. Melihat banyak dan pentingnya fungsi hati, maka jika terjadi kerusakan pada hati akan mempengaruhi fungsi jaringan tubuh lainnya (Niranjan, 2016; Ozougwo, 2017).

Tanaman herbal berkhasiat dapat mengobati penyakit pada hati. Arsad et al. (2014), menjelaskan bahwa ekstrak Rhaphidophora decursiva asal masyarakat cina di Malaysia pada dosis tertentu dapat memperbaiki kerusakan mikroanatomi hati mencit. Menurut Tatukude et al. (2014), pemberian air rebusan sarang semut dosis $0,24 \mathrm{cc} /$ hari selama 10 hari menunjukkan regenerasi sel-sel hati dan selama 14 hari tingkat maturasi sel hati lebih baik.

Penggunaan obat tradisional secara terus menerus dalam jangka waktu lama dikhawatirkan memberikan efek samping terhadap organ-organ vital dalam tubuh. Penggunaan ramuan obat pahit masyarakat Melayu Lingga belum memiliki standarisasi tentang penggunaan dosis sehingga perlu dilakukan penelitian mengenai struktur histologi hati tikus putih setelah diberikan ramuan obat pahit masyarakat Melayu Lingga dengan tiga jenis ramuan yang berbeda pada tingkatan dosis yang berbeda. Penelitian ini bertujuan untuk mengkaji gambaran histologi hati tikus putih setelah pemberian rebusan ramuan obat pahit sehingga informasi ini dapat menjadi informasi dasar mengenai pengaruh pemberian ramuan obat pahit masyarakat Melayu Lingga terhadap histologi organ hati. 


\section{METODE PENELITIAN}

\section{Pembuatan Rebusan Ramuan Obat Pahit}

Pembuatan rebusan ramuan obat pahit 100 gram dengan $1000 \mathrm{ml}$ akuades. Hasil rebusan ramuan diambil sebanyak $200 \mathrm{ml}$ untuk digunakan dalam proses pencekokan. Rebusan ramuan obat pahit diberikan terhadap tikus sebanyak dua kali (pagi dan sore) penggunaan dalam sehari.

\section{Penetapan Dosis Hewan Coba}

Penetapan dosis tikus putih berdasarkan Lawrance \& Bacharach (1964) dengan mengkonversikan dosis yang umumnya diminum oleh manusia $(200 \mathrm{ml})$ dengan faktor konversi tikus 0.018 . Sediaan yang dibuat adalah $100 \mathrm{~g}$ dalam $1000 \mathrm{ml}$, sehingga volume yang diberikan adalah dosis konversi berbanding berat sediaan dikali volume maksimal atau $3.6 / 100$ x $5=0.18 \mathrm{ml} / 200 \mathrm{~g}$ BB yang ditetapkan sebagai dosis 2 rute pemberian IROP secara oral. Kemudian dosis dibuat bertingkat yaitu $0.9 \mathrm{ml} / 200 \mathrm{~g}$ BB, $0.18 \mathrm{ml} / 200 \mathrm{~g} \quad \mathrm{BB}, \quad 0.27$ $\mathrm{ml} / 200 \mathrm{~g} \mathrm{BB}$ dan $0.36 \mathrm{ml} / 200 \mathrm{~g} \mathrm{BB}$.

\section{Uji In Vivo}

Penelitian ini merupakan penelitian eksperimen yang dilakukan di Kandang tikus sebanyak 45 ekor tikus putih jantan berumur 3 bulan dengan berat badan sekitar $170 \mathrm{~g}-260 \mathrm{~g}$. Sebanyak 9 ekor tikus digunakan sebagai kelompok kontrol postif, kontrol negatif dan kontrol normal. Ramuan obat pahit yang direbus, diberikan secara oral terhadap tikus putih jantan sebanyak 36 ekor yang diberikan setiap 2 kali sehari selama 11 hari dengan menggunakan spuit disposibleukuran $1 \mathrm{ml}$ tanpa jarum. Selanjutnya pada hari ke-11 semua tikus putih dieuthanasi dengan larutan kloroform untuk dilakukan pembedahan dan mengambil sampel organ hati tikus putih jantan.

\section{Analisis Data \\ Analisis data menggunakan program SPSS dengan uji One-way ANOVA dengan $\alpha=0.05$ yang bertujuan untuk melihat perbedaan nyata antar kelompok perlakuan. Jika nilai probabilitas (p) $>0.05$ diterima sebagai hal yang tidak berbeda nyata. Sedangkan jika nilai probabilitas $(\mathrm{p})<0.05$ maka diterima sebagai hal yang berbeda nyata maka dilanjutkan dengan uji Duncan Multiple Range Taste (DMRT).}

Tabel 1. Parameter skoring evaluasi hati pada 5 lapang pandang di sekitar vena sentralis (Baldatina, 2008):

\begin{tabular}{ll}
\hline Nilai skor & \multicolumn{1}{c}{ Perubahan HP ( Histopatologis) } \\
\hline 0 Jika $<25 \%$ & $\begin{array}{l}\text { Hati mengalami degenerasi hidropik, degenarasi Parenkim dan } \\
\text { apoptosis di sekitar Sentrolobuler (vena sentralis) }\end{array}$ \\
1 Jika 25-50\% & $\begin{array}{l}\text { Hati Mengalami degenerasi hidropik, degenerasi Parenkim dan } \\
\text { apoptosis yang meluas hingga ke daerah tengah (midzona) }\end{array}$ \\
2 Jika 50-75\% & $\begin{array}{l}\text { Hati Mengalami degenerasi hidropik, degenerasi Parenkim dan } \\
\text { apoptosis yang meluas hingga ke periporta (perilobuler) }\end{array}$ \\
3 Jika $>75 \%$ & $\begin{array}{l}\text { Hati Mengalami degenerasi hidropik, degenerasi Parenkim dan } \\
\text { apoptosis yang meluas hingga ke zona Periporta (Perilobuler) }\end{array}$
\end{tabular}

Ket: nilai skoring 0: Normal, 1: Ringan, 2: Sedang, 3: Berat

\section{HASIL DAN PEMBAHASAN}

\section{Makroskopis Hati Tikus Putih (Rattus norvegicus B.)}

Berdasarkan hasil pengamatan secara makroskopis diketahui bahwa hati tikus putih yang diberikan tiga jenis ramuan obat pahit dengan beberapa tingkatan dosis yang berbeda, menunjukkan perbedaan warna antara kelompok perlakuan Kalan (dosis 2 H5R4/8), SP4 (dosis 1 dan dosis 2 H5R3/10 dan dosis 4 H5R4/8) dan Linau (dosis 1 dosis 2 H5R4/8, dosis 3 dan dosis 4 H5R3/10) terhadap kelompok kontrol positif (H5R3/8) dan kontrol negatif (H5R2/6) (Gambar 1).

Namun pada kelompok perlakuan Kalan (dosis 1, dosis 3 dan dosis 4 memiliki gradasi warna H5R3/8) yang berarti tidak berbeda terhadap kelompok kontrol postif yaitu berwarna merah kecokelatan.Menurut Lailatul et al. (2015), hati yang normal memiliki warna merah kecokelatan.Hal ini disebabkan karena banyaknya darah mengalir yang difasilitasi oleh pembuluh darah. Fortes (2017), juga menyatakan bahwa hati yang normal akan berwarna merah kecokelatan yang disebabkan oleh aliran darah yang masuk ke organ hati.

Pada kelompok perlakuan menggunakan ramuan SP4 terjadi perubahan gradasi warna seiring peningkatan dosis yaitu gradasi warna semakin gelap.namun terjadi perubahan warna semakin pucat pada dosis 4.Berbeda halnya yang terjadi pada kelompok perlakuan menggunakan ramuan Linau, pada dosis 1 hati berwarna pucat namun seiring peningkatan dosis gradasi warna hati mendekati warna kontrol positif. Menurut Westbrook (2016), hati yang berwarna pucat disebabkan oleh pelepasan asam-asam lemak bebas secara cepat yang berasal dari lemak visceral (lemak yang menempel padaorgan di dalam tubuh) yang membesar. Fortes 
(2017), menyatakan bahwa penyebab hati berwarna pucat adalah senyawa yang bersifat toksik yang menyebabkan perlemakan pada hati. Menurut Lailatul et al. (2015), hal tersebutakan menggangu aliran darah ke hati sehingga hati berwarna pucat.
Junqueira \& Carneiro (2007), menyatakan bahwa senyawa toksik dapatmasuk kedalam tubuh melalui makanan, karena hati $80 \%$ menyuplai darah dari saluran pencernaan
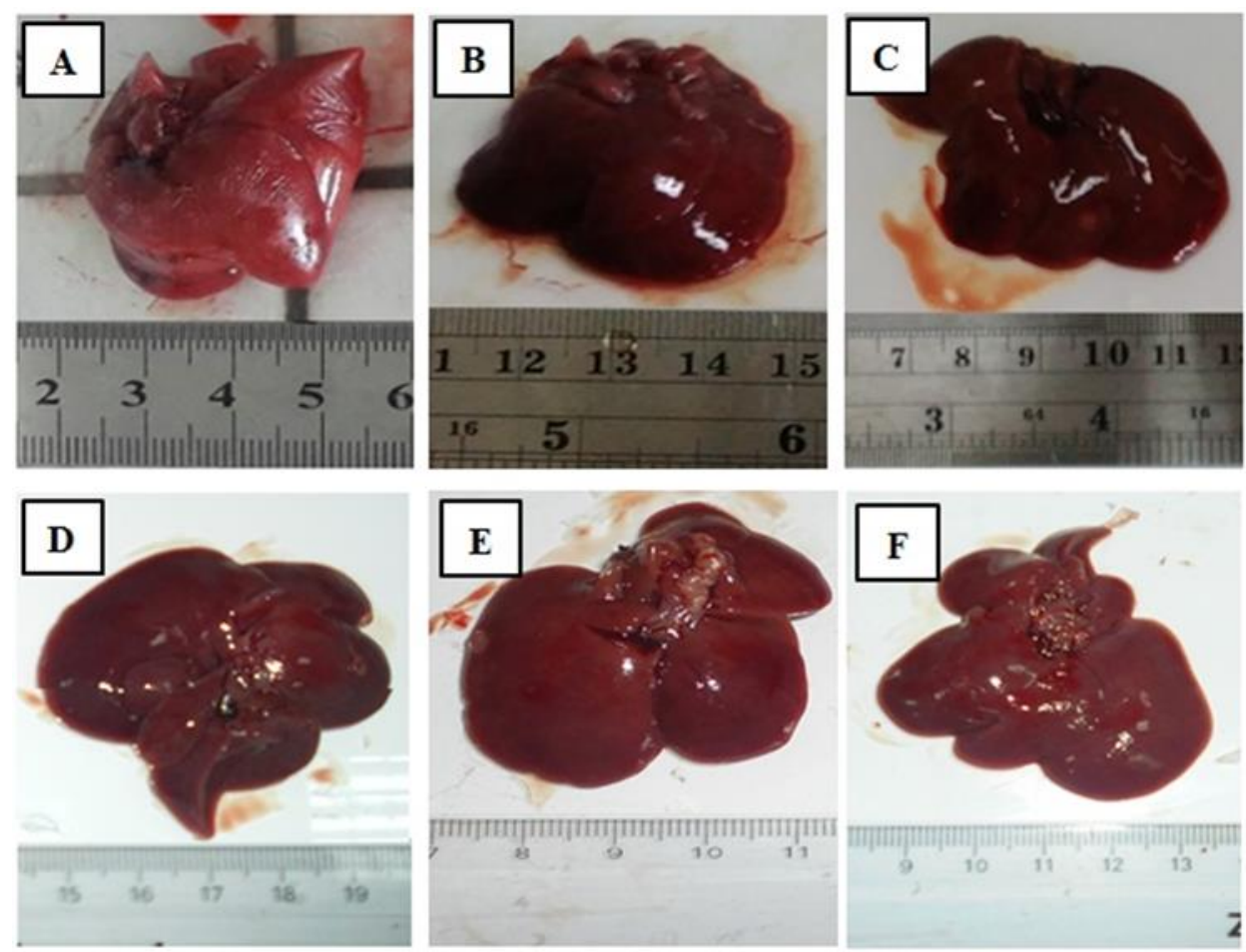

Gambar 1. Morfologi hati tikus putih (Rattus norvegicus) A. Kontrol (0), B. Kontrol (+), C. Kontrol (-), D. Ramuan Kalan dosis 1, E. Ramuan SP4 dosis 1, F. Ramuan Linau dosis 1.

\section{Mikroskopis Hati Tikus Putih (Rattus norvegicus B.)}

Pengamatan mikroskopis yaitu melihat struktur histologi hati dari sayatan preparat awetan hati.Hal ini bertujuan untuk melihat kerusakan jaringan hati setelah pemberian tiga jenis ramuan obat pahit.Hasil pengamatan menunjukkan jumlah rata-rata persentase kerusakan hepatosit berbedapada setiap perlakuan dan setiap dosis.Data jumlah kerusakan hepatosit dapat dilihat pada (Tabel 2).

Tabel 2. Persentase kerusakan hepatosit tikus putih akibat pemberian ramuan obat pahit

\begin{tabular}{|c|c|c|c|}
\hline & Ramuan & Persentase Kerusakan (\%) & Skoring Kerusakan \\
\hline Kontrol & $\begin{array}{l}\text { Stimuno }(\mathrm{k}+) \\
\text { Aquades }(\mathrm{k} 0) \\
\text { CMC Na } 1 \%(\mathrm{k}-)\end{array}$ & $\begin{array}{l}18,09 \pm 1,22^{\mathrm{ab}} \\
14,89 \pm 2,77^{\mathrm{a}} \\
49,92 \pm 6,53^{\mathrm{d}}\end{array}$ & $\begin{array}{l}0 \\
0 \\
1\end{array}$ \\
\hline Kalan & $\begin{array}{l}\text { D1 }(0,9 \mathrm{ml}) \\
\text { D2 }(1,8 \mathrm{ml}) \\
\text { D3 }(2,7 \mathrm{ml}) \\
\text { D4 }(3,6 \mathrm{ml})\end{array}$ & $\begin{array}{l}18.80 \pm 3.09^{\mathrm{ab}} \\
19.13 \pm 0,89^{\mathrm{ab}} \\
21.79 \pm 3,48^{\mathrm{bc}} \\
21.07 \pm 4,04^{\mathrm{bc}}\end{array}$ & $\begin{array}{l}0 \\
0 \\
0 \\
0\end{array}$ \\
\hline SP4 & $\begin{array}{l}\text { D1 }(0,9 \mathrm{ml}) \\
\text { D2 }(1,8 \mathrm{ml}) \\
\text { D3 }(2,7 \mathrm{ml}) \\
\text { D4 }(3,6 \mathrm{ml})\end{array}$ & $\begin{array}{l}22.62 \pm 1,44^{\mathrm{bc}} \\
23.73 \pm 2,19^{\mathrm{bc}} \\
23.27 \pm 2,72^{\mathrm{bc}} \\
26.13 \pm 3,73^{\mathrm{c}}\end{array}$ & $\begin{array}{l}0 \\
0 \\
0 \\
1\end{array}$ \\
\hline Linau & $\begin{array}{l}\text { D1 }(0,9 \mathrm{ml}) \\
\text { D2 }(1,8 \mathrm{ml}) \\
\text { D3 }(2,7 \mathrm{ml}) \\
\text { D4 }(3,6 \mathrm{ml})\end{array}$ & $\begin{array}{l}20.39 \pm 1,43^{\mathrm{abc}} \\
21.35 \pm 3,11^{\mathrm{bc}} \\
21.22 \pm 2,29^{\mathrm{bc}} \\
22.95 \pm 2,15^{\mathrm{bc}}\end{array}$ & $\begin{array}{l}0 \\
0 \\
0 \\
0\end{array}$ \\
\hline
\end{tabular}

Keterangan : D1 (Dosis 1), D2 (Dosis 2), D3(Dosis 3), dan D4 (Dosis 4) 
Persentase kerusakan paling sedikit terjadi pada kelompok kontrol normal yang diberikan aquades (Tabel 2). Hal ini dimungkinkan karena tidak adanya pengaruh zat toksik masuk kedalam tubuh. Sehingga persentase kerusakan yang ditemukan tidak banyak. Namun kerusakan tetap terjadi pada kelompok kontrol normal. Hal ini bisa disebabkan karena pengaruh faktor eksternal seperti kondisi lingkungan dan makanan yang tidak higienis sehingga dapat menyebabkan gangguan kesehatan pada tikus. Pada kontrol positif yang diberikan stimuno juga ditemukan kerusakan hepatosit yang sedikit.Hal ini dikarenakan stimuno merupakan senyawa antioksidan yang sudah teruji sebagai penambah stamina.Sedikitnya persentase kerusakan yang diperoleh akibat pemberian stimuno karena antioksidan yang terdapat dalam stimuno yang tidak bersifat toksik (Sujono et al., 2015). Namun pada kelompok kontrol negatif yang diberikan larutan CMC Na $1 \%$ ditemukan kerusakan paling banyak diantara semua perlakuan.

Berdasarkan parameter skoring, kerusakan yang terjadi pada kelompok kontrol normal dan kontrol positif adalah 0 .Hal ini dinyatakan bahwa kerusakan yang terjadi pada hepatosit hati masih dalam kategori normal.Namun berbeda halnya dengan skoring kontrol negatif yang memiliki skoring 1.Hal ini dinyatakan bahwa kerusakan yang terjadi dikategorikan mengalami kerusakan ringan (Baldatina, 2008).

Pada kelompok perlakuan yang menggunakan ramuan Kalan persentase kerusakan paling sedikit terjadi pada dosis 1 yaitu $18.80 \pm 3.09$ dan persentase kerusakan paling banyak terjadi pada dosis 4 yaitu 21.07 4 4,04. Pada kelompok perlakuan yang menggunakan ramuan SP4 persentase kerusakan yang paling rendah ditemukan pada dosis 1 yaitu $22.62 \pm 1,44$ dan persentase kerusakan paling tinggi ditemukan pada dosis 4 yaitu $26.13 \pm 3,73$. Sedangkan kelompok perlakuan yang menggunakan ramuan Linau pada dosis 1 juga memiliki persentase kerusakan paling rendah yaitu 20.39 $\pm 1,43$ dan dosis 4 memiliki persentase kerusakan paling tinggi yaitu $22.95 \pm 2,15$.Secara keseluruhan, persentase kerusakan pada kelompok perlakuan yang diberikan tiga jenis ramuan obat pahit dengan tingkatan dosis yang berbeda kerusakan paling sedikit ditemukan pada dosis $1(0,09 \mathrm{ml} / 200 \mathrm{~g} \mathrm{BB})$ dan kerusakan yang paling banyak ditemukan pada dosis $4(0,36 \mathrm{ml} / 200 \mathrm{~g} \mathrm{BB})$. Hal ini menunjukkan bahwa penggunaan ramuan obat pahit, semakin tinggi dosis yang diberikan menyebabkan kerusakan yang semakin banyak.Hal ini dimungkinkan karena pengaruh senyawa fitokimia tumbuhan yang terdapat dalam ramuan obat pahit.Sesuai dengan penelitian yang dilakukan oleh Tatukude (2014), bahwa rebusan air sarang semut dengan dosis 0,24 cc/hari selama 10 hari menunjukkan regenerasi sel. Namun menimbulkan perlemakan pada dosis $0,48 \mathrm{cc} /$ hari selama 10 hari. Dosis 1 mengalami kerusakan paling sedikit karena merupakan dosis yang paling rendah pada setiap perlakuan. Kurniawan et al. (20014) dalam penelitiannya menyatakan bahwa dosis $0,5 \mathrm{~g} / \mathrm{kgBB}$ dan $1,5 \mathrm{~g} / \mathrm{kgBB}$ tidak menyebabkan kerusakan.

Diantara tiga jenis ramuan yang digunakan, persentase kerusakan paling sedikit terjadi pada kelompok perlakuan yang menggunakan ramuan Kalan dosis $1(0,9 \mathrm{ml})$ yaitu 18.80 \pm 3.09 .Sedangkan persentase kerusakan paling banyak terdapat pada kelompok perlakuan yang menggunakan ramuan SP4 dosis $4(3,6 \mathrm{ml})$ yaitu $26.13 \pm 3,73$. Hal ini dimungkinkan karena pengaruh jumlah komposisi tumbuhan yang terdapat dalam masing-masing ramuan, dimana ramuan Kalan memiliki komposisi jumlah tumbuhan yang paling sedikit dibandingkan dengan komposisi jumlah tumbuhan yang terdapat dalam ramuan SP4 yang memiliki komposisi jumlah tumbuhan yang paling banyak.Hal ini dimungkinkan karena pengaruh senyawa fitokimia yang terdapat dalam setiap tumbuhan pada masing-masing ramuan obat pahit tersebut.

Berdasarkan skoring menurut Baldatina (2008), persentase kerusakan hepatosit hati akibat pemberian tiga jenis ramuan obat pahit dan dengan tingkatan dosis yang berbeda dinyatakan bahwa persentase kerusakan hepatosit memiliki skoring 0 . Hal ini dinyatakan bahwa persentase kerusakan yang terjadi pada hepatosit hati akibat dari pemberian tiga jenis ramuan yang berbeda masih dalam keadaan normal.Namun seiring peningkatan dosis yang diberikan persentase kerusakan semakin naik.Hal ini di mungkinkan karena senyawa fitokimia tumbuhan yang terdapat dalam masing-masing ramuan obat pahit sehingga menyebabkan persentase kerusakan semakin banyak seiring peningkatan dosis.

Hasil uji One-Way Anova Tabel 4.2.1 menunjukkan nilai $\mathrm{P}<0.05$ maka dinyatakan bahwa terdapat perbedaan yang nyata kerusakan hepatosit hati tikus putih anatara kelompok perlakuan yang diberikan tiga jenis ramuan obat pahit dengan tingkatan dosis yang berbeda terhadap kelompok kontrol.Sehingga dilanjutkan dengan uji DMRT. Hasil uji lanjut DMRT menunjukkan bahwa perbedaan nyata terdapat pada kelompok perlakuan yang diberikan tiga jenis ramuan obat pahit terhadap kelompok kontrol negatif.Sedangkan terhadap kelompok kontrol normal dan kelompok kontrol positif tidak terdapat perbedaan kerusakan yang nyata.Hal ini dinyatakan bahwa kerusakan yang terjadi pada hepatosit hati tikus putih yang diberikan ramuan obat pahit tidak memberikan kerusakan yang parah terhadap histologi hati.Namun kerusakan yang terjadi pada kelompok perlakuan yang diberikan tiga jenis ramuan obat pahit kemungkinan disebabkan karena senyawa fitokimia tumbuhan yang terdapat dalam ramuan obat pahit (Gambar 2). 


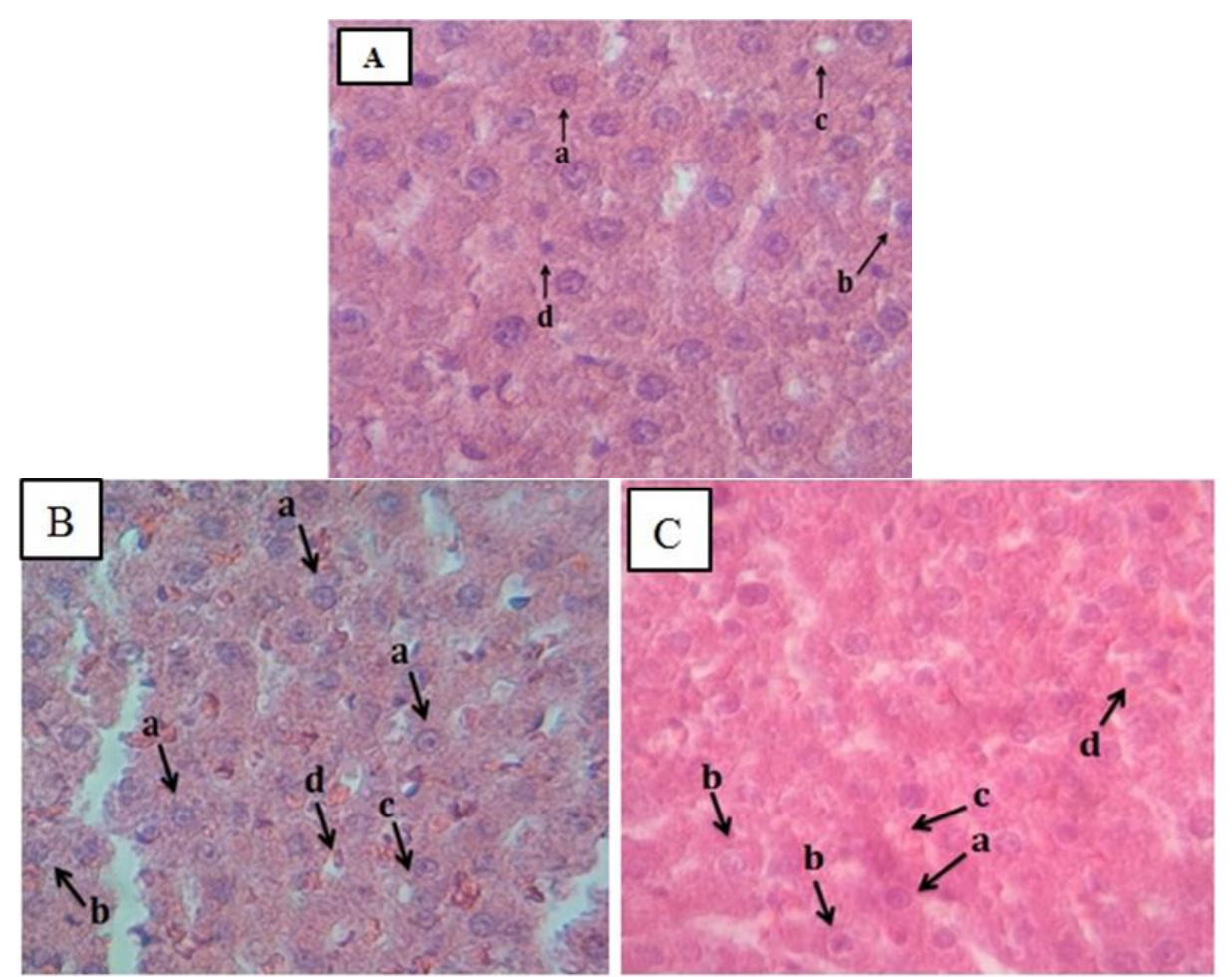

Gambar 2. Histologi hati tikus putih kelompok kontrol.menggunakan pewarnaan HE (perbesaran 16 x 40) A. Kontrol normal, B. Kontrol positif, C. Kontrol negatif. keterangan : a. hepatosit normal, b. degenerasi hidropis, c. degenerasi lemak, d. nekrosis.

Pada kelompok kontrol normal, kontrol positif maupun kontrol negatif ditemukan kerusakan pada hepatosit hati tikus putih di antaranya adalah degenerasi dan nekrosis (Gambar 2). Kontrol normal hanya diberikan aquades sehingga kerusakan yang terjadi pada hepatosit hati tidak terlalu banyak. Hasil pengamatan histologi hati pada kontrol positif yang diberikan stimuno, juga ditemukan beberapa jenis kerusakan namun sama halnya dengan yang terjadi pada kontrol normal kerusakan yang terjadi ditemukan hanyalah sedikit. Nekrosis yang terjadi pada kelompok kontrol merupakan tidak termasuk kedalam kejadian patologi, karena nekrosis juga terjadi dalam keadaan normal (Cheville,
1999).Sedangkan pada kontrol negatif yang diberikan larutan $\mathrm{CMC} \mathrm{Na} 1 \%$ juga ditemukan jenis kerusakan yang sama dengan kontrol positif dan kontrol normal. Namun persentase jumlah kerusakan yang terjadi pada kontrol negatif memiliki skoring 1 yang artinya kerusakan yang terjadi masih dalam kategori ringan. Adapun kerusakan hepatosit yang ditemukan pada setiap kelompok kontrol di mungkinkan karena pengaruh makanan yang tidak higienis ataupun faktor eksternal seperti lingkungan sehingga menyebabkan gangguan kesehatan tikus. Pada kelompok perlakuan yang diberikan ramuan obat pahit jenis Kalan juga ditemukan beberapa jenis kerusakan (Gambar 3).
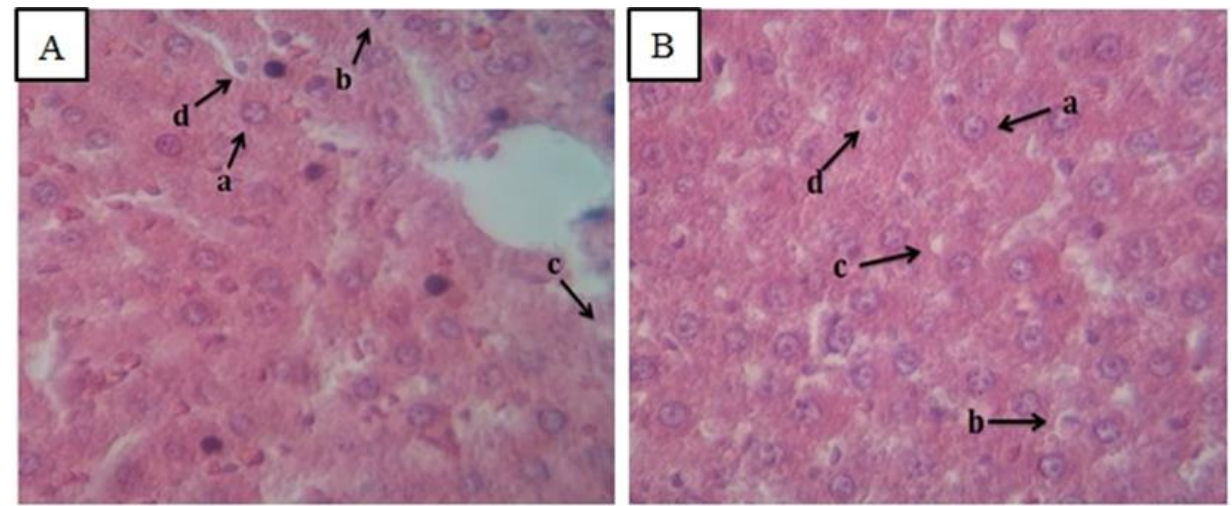

Gambar 3. Histologi hati tikus putih yang diberikan ramuan Kalan.menggunakan pewarnaan HE (perbesaran $16 \mathrm{x}$ 40) A. dosis 1, B. dosis 2. keterangan : a. hepatosit normal, b. degenerasi hidropis, c. degenerasi lemak, d. nekrosis. 

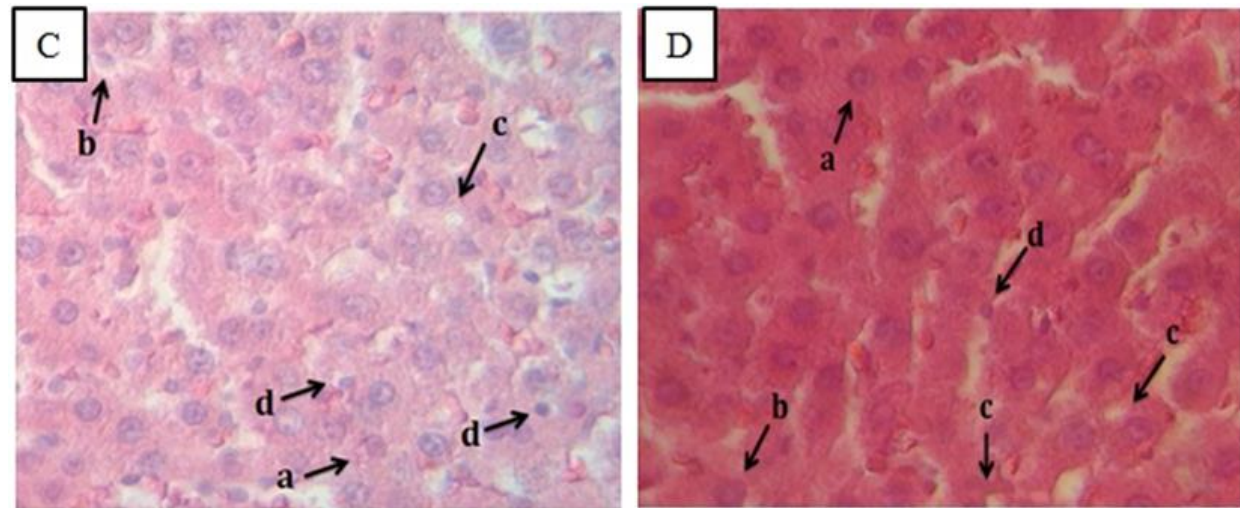

Gambar 4. Histologi hati tikus putih yang diberikan ramuan Kalan.menggunakan pewarnaan HE (perbesaran $16 \mathrm{x}$ 40) C. dosis 3, D. dosis 4. keterangan : a. hepatosit normal, b. degenerasi hidropis, c. degenerasi lemak, d. nekrosis

Gambaran histologi hati dengan pemberian ramuan Kalan ditemukan kerusakan seperti degenerasi hidropis, degenerasi lemak dan nekrosis pada setiap dosis. Hasil pengamatan menunjukkan bahwa pada dosis 1 , merupakan tingkat kerusakan yang paling rendah. Kerusakan lebih banyak ditemukan seiring peningkatan dosis yaitu pada dosis 4. Namun persentase jumlah kerusakan yang terjadi berdasarkan parameter skoring, kerusakan histologi hati masih dalam kategori normal (Gambar 3).

Degenerasi hidropis merupakan salah satu kerusakan yang ditemukan pada hepatosit hati tikus putih pada kelompok perlakuan Kalan (Gambar 4).
Degenerasi hidropis merupakan kerusakan sel yang dicirikan dengan pembengkakan sitoplasma (Harada et al. 1999). Menurut Robbins et al., (2007), degenerasi hidropis terjadi karena terganggunya transport aktif yang mengakibatkan sel tidak mampu memompa ion $\mathrm{Na}+$ keluar sehingga konsentrasi ion $\mathrm{Na}+$ di dalam sel naik. Menurut McGavin et al. (2007), kebengkakan sitoplasma yamg terjadi merupakan manifestasi akumulasi cairan yang berlebihan akibat kegagalan sel dalam mempertahankan homeostasis.Sedangkan gambaran histlogi hati tikus putih akibat pemberian ramuan SP4 dapat dilihat pada (Gambar 5).
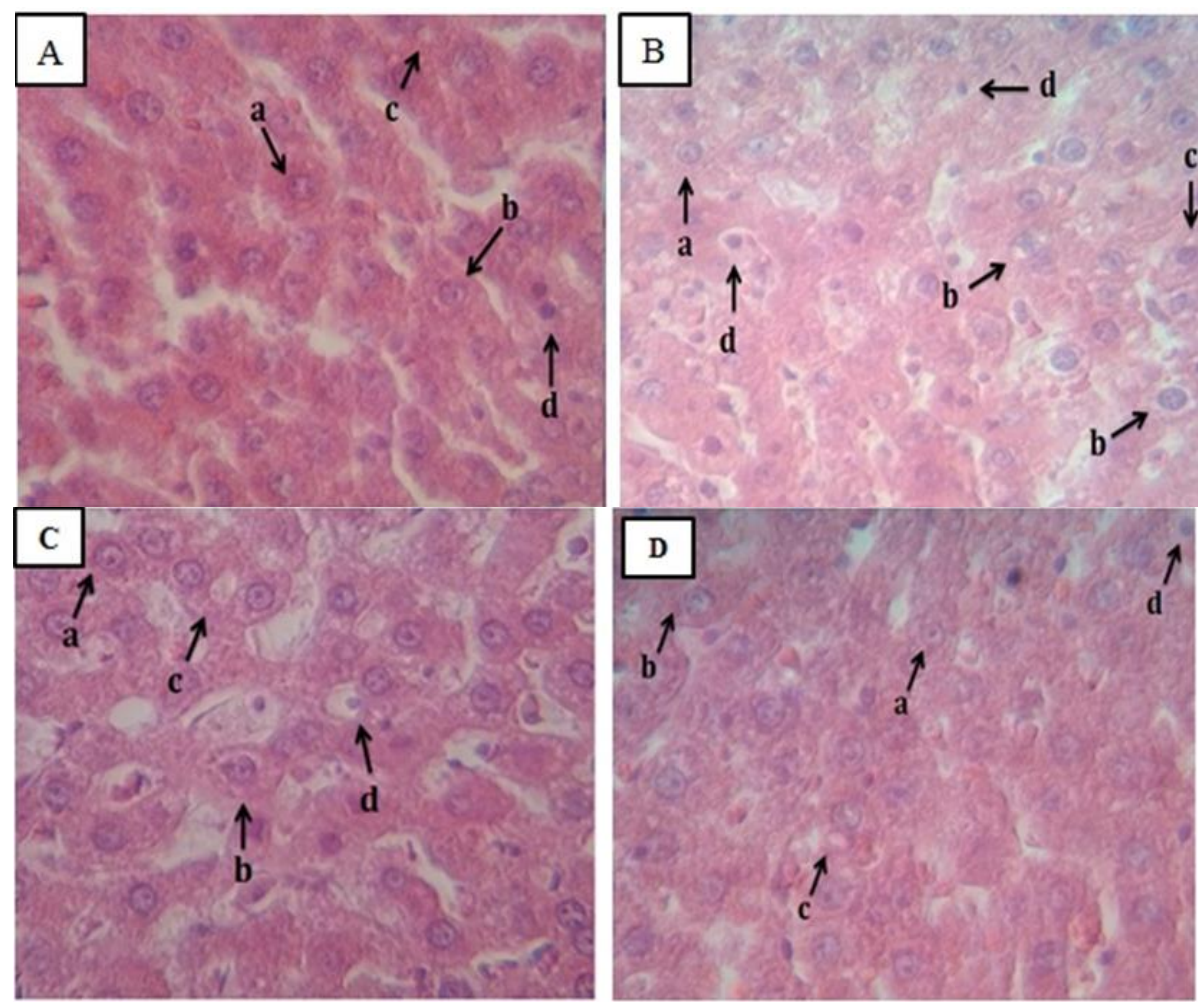

Gambar 5. Histologi hati tikus putih yang diberikan ramuan SP4.menggunakan pewarnaan HE (perbesaran 16 x 40) A. dosis 1, B. dosis 2, C. dosis 3. D. dosis 4.keterangan : a. hepatosit normal, b. degenerasi hidropis, c. degenerasi lemak, d. nekrosis 
Penggunaan ramuan SP4 menunjukkan tingkat kerusakan lebih banyak seiring peningkatan dosis yang digunakan. Jenis kerusakan yang terjadi pada hepatosit adalah degenerasi hidropis, degenerasi lemak dan nekrosis (Gambar 5). Kerusakan lebih banyak ditemukan pada dosis 3 dan dosis 4 . Hal ini dimungkinkan karena ramuan SP4 memiliki komposisi tumbuhan lebih banyak dibandingkan jumlah komposisi tumbuhan yang terdapat pada ramuan Kalan.Sehingga jumlah senyawa kimia yang masuk kedalam tubuh akan bertambah banyak.

Kelompok perlakuan yang diberikan ramuan SP4 dinyatakan tidak berbeda nyata terhadap kelompok kontrol normal dan kelompok kontrol positif.Namun kerusakan lebih banyak ditemukan akibat pemberian ramuan SP4 jika dibandingkan dengan persentase kerusakan yang terjadi pada kelompok perlakuan yang diberikan ramuan Kalan.Namun persntase kerusakan yang ditemukan akibat ramuan SP4 berbeda nyata terhadap kontrol negatif. Hal ini jika dilihat dari jumlah jenis tumbuhan yang termasuk dalam ramuan SP4 terdapat lebih banyak jika dibandingkan dengan jumlah jenis tumbuhan yang terdapat pada ramuan Kalan.

Berdasarkan hasil pengamatan, menunjukkan bahwa jenis kerusakan yang banyak adalah degenerasi lemak. Riset Kurniawan et al., (2014), menjelaskan bahwa penyebab degenerasi lemak adalah komponen alkaloid dalam tumbuhan yang terdapat dalam ramuan SP4. Degenerasi lemak merupakankelanjutan dari degenerasi hidropis yang telah mengalami kerusakan permanen (irreversible). Degenerasi lemak merupakan respon sel hepatosit terhadap toksikan yang merusak jalur metabolisme lemak (Lu, 1995). Degenerasi lemak merupakan kerusakan hepatosit yang ditandai dengan perubahan morfologi dan penurunan fungsi organ hati karena terjadinya akumulasi lemak yang terdapat di dalam sitoplasma sel hati.Jika dilihat secara mikroskopis sel terlihat bercak-bercak lemak kecil berwarna jernih. Hal ini dapat terjadi karena kondisi iskemia, anemia, gangguan bahan tosik, kelebihan konsumsi lemak dan protein (Dannuri, 2009).

Secara umum beberapa tumbuhan yang terdapat dalam ramuan Kalan juga terdapat dalam ramuan SP4.Namun jumlah komposisi jenis tumbuhan yang terdapat dalam ramuan SP4 lebih banyak.Sehingga senyawa fitokimia yang dihasilkan juga lebih banyak.Hal ini dimungkinkan menyebabkan persentase kerusakan hepatosit pada ramuan SP4 berbeda dari pada persentase kerusakan hepatosit ramuan Kalan. Banyaknya senyawa kimia yang masuk kedalam tubuh menyebkan proses kerja hati lebih berat dalam detoksifikasi.

Beberapa kerusakan juga terjadi pada hati tikus putih yang disebabkan oleh ramuan obat pahit jenis Linau. Adapun gambaran histologi hati tikus putih yang disebabkan oleh ramuan obat pahit jenis Linau (Gambar 6).

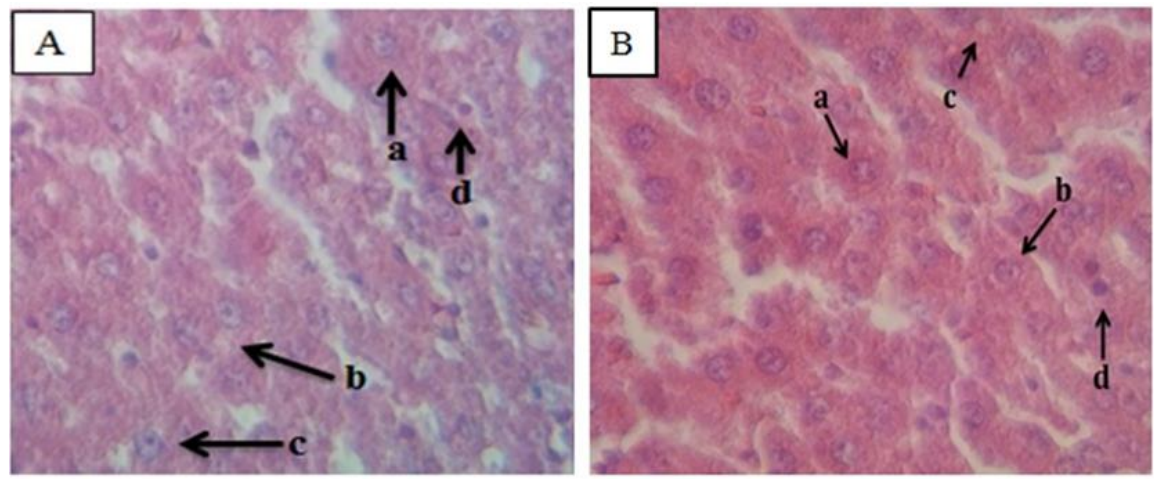

Gambar 6. Histologi hati tikus putih yang diberikan ramuan Linau.menggunakan pewarnaan HE (perbesaran $16 \mathrm{x}$ 40) A. dosis 1, B. dosis 2, keterangan : a. hepatosit normal, b. degenerasi hidropis, c. degenerasi lemak, d. nekrosis.

Kerusakan yang ditemuakan pada pada histologi hati diantaranya adalah degenerasi dan juga nekrosis (Gambar 7). Hal ini sama dengan kerusakan yang ditemukan pada kelompok perlakuan yang diberikan ramuan Kalan dan ramuan SP4. Pada kelompok perlakuan yang menggunakan ramuan Linau, kerusakan yang banyak ditemukan adalah degenerasi lemak dan nekrosis.Tingkat kerusakan yang ditemukan semakin banyak seiring peningkatan dosis. Hal ini terjadi karena semakin banyaknya senyawa kimia yang masuk ke dalam tubuh maka hati akanbekerja semakin berat, karena hati akan mendetoksifikasi senyawa-senyawa yang masuk kedalam tubuh terutama senyawa yang masuk melalui saluran pencernaan (Lu, 1995).

Kerusakan hepatosit pada kelompok kontrol normal dan kontrol positif tidak berbeda nyata dengan kelompok perlakuan dosis 1 .Namun berbeda nyata dengan dosis 2 , dosis 3 , dosis 4 dan kontrol negatif. Sedangkan dosis 2, dosis 3 dan dosis 4 berbeda nyata dengan kelompok kontrol negatif dan kontrol positif, namun tidak berbeda nyata dengan dosis 1 . Sehingga penggunaan dosis 2 , dosis 3 dan dosis 4 masih bagus untuk digunakan. Namun 
penggunaan dosis paling baik untuk digunakan pada ramuan Linau adalah dosis 1 .Hal ini dimungkinkan karena pengaruh dari jenis dan jumlah tumbuhan serta kandungan senyawa fitokimia yang terdapat pada masing-masing ramuan obat pahit tersebut.Salah satu senyawa fitokimia yang mungkin terdapat dalam beberapa jenis tumbuhan pada ramuan obat pahit adalah alkaloid, (Moharram dalam Wicaksono, 2015), menyatakan alkaloid dapat merusak sel hati. Sehingga diduga bahwa senyawa kimia pada tumbuhan yang terdapat dalam ramuan dapat menyebabkan persentase jumlah kerusakan antar kelompok perlakuan. Apabila proses degenerasi sel terjadi secara terus menerus maka akan mencapai kerusakan yang permanen dan sel mengalami kematian. Menurut Chaville (1999), nekrosis merupakan kematian sel yang ditandai dengan ciriciri kromatin inti dapat membentuk menggumpal (piknosis), pecah (karyorexis) dan menghilang (kalryolisis).
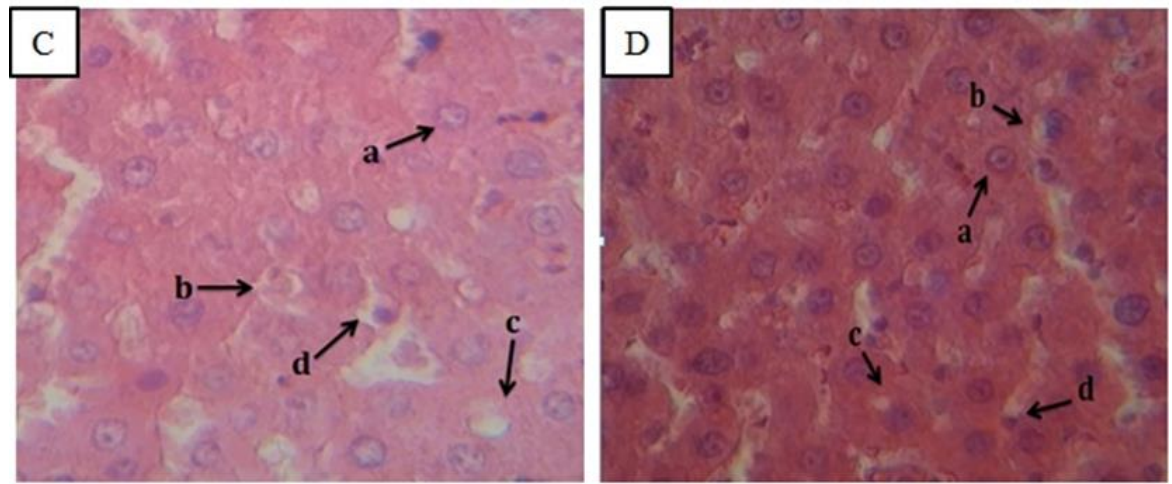

Gambar 7. Histologi hati tikus putih yang diberikan ramuan Linau.menggunakan pewarnaan HE (perbesaran $16 \mathrm{x}$ 40) C. dosis 3. D. dosis 4.keterangan : a. hepatosit normal, b. degenerasi hidropis, c. degenerasi lemak, d. nekrosis

\section{KESIMPULAN DAN SARAN}

Pemberian ramuan obat pahit dengan tiga jenis ramuan yang berbeda secara morfologi, hati tikus putih terdapat perbedaan warna terhadap kelompok kontrol. Persentase kerusakan hepatosit hati tikus putih akibat pemberian tiga jenis ramuan obat pahit yang berbeda dengan tingkatan dosis yang berbeda paling sedikit terjadi pada kelompok perlakuan Kalan dosis1. Persentase kerusakan paling banyak terjadi pada kelompok perlakuan SP4 dosis 4. Nilai skoring kerusakan hepatosit setiap perlakuan akibat pemberian tiga jenis ramuan yang berbeda dan tingkatan dosis yang berbeda adalah 0, kecuali pada ramuan SP4 dosis 4 nilai skoring kerusakan adalah 1. Persentase kerusakan antar perlakuan tidak terdapat perbedaan nyata terhadap kelompok kontrol normal dan kontrol positif namun berbeda nyata terhadap kelompok kontrol negatif. Sehingga secara umum bahwa pemberian tiga jenis ramuan obat pahit yang berbeda dengan tingkatan dosis yang berbeda memberikan kerusakan semakin meningkat seiring peningkatan dosis. Namun kerusakan yang terjadi masih dalam kategori normal.

\section{DAFTAR PUSTAKA}

Arsad S.S., Esa N.M. and Hamzah H. 2014. Histopathologic Changes in Liver and Kidney Tissues from Male Sprague Dawley Rats Treated with Rhaphidophora Decursiva (Roxb.) Schott Extract. Journal of Cytology \& Histology. S4: 001. doi: 10.4172/2157-7099.S4-001.
Baldatina A.Z.I. 2008. Pengaruh Pemberian Insektisida (Esbiothrin, Imiprothrin dan DPhenothrin) pada Tikus Putih (Rattus rattus): Kajian Histopatologi Hati dan Ginjal. Fakultas Kedokteran Hewan. Institut Petanian Bogor. Bogor.

Cheville N.F. 1999. Introduction to Veterinary Pathology. USA: Lowa State University Press.

Dannuri H. 2009. Analisis Enzim Alanin Amino Tranferase (ALAT), Aspartat Amino Transferase (ASAT), Urea Darah, dan Histopatologis Hati dan Ginjal Tikus Putih Galur Sprague-Dawley Setelah Pemberian Angklak. J Teknol dan Industri Pangan 20(1):1-9.

Fitmawati, Sofiyanti N., Roza R.M., Isnaini, Hazimi H., Irawan Y.R., Winata D.R. and Dewi A.P.K. 2017. Traditional medicinal formulation: Obat pahit from Lingga Malay Ethnic in Riau Archipelago, Indonesia. Biodiversitas. 18(3): 1196-1200.

Fortes R.C. 2017. Nutritional Implications in Chronic Liver Diseases. Journal of Liver Research, Disorders \& Therapy. 3(5). 00071. DOI: 10.15406/jlrdt.2017.03.0007.

Junqueira L.C. Carneiro J. 2007. Histologi Dasar. Jakarta: EGC.

Kurniawan W.A.Y., Ngurah I.W. dan Ni W.S. 2014. Histologi hati mencit (Mus musculus 1.) yang diberi ekstrak daun lamtoro (Leucaena leucocephala). Jurnal Simbiosis II (2):226-235

Lailatul N.F., Diana L.Y. dan Mudjiwijono H. 2015. Efek pemberian asam alfa lipoat terhadap kadar MDA dan gambaran histologi pada hati tikus 
model diabetes melitus tipe 1. Jurnal Kedokteran Brawijaya. 28(3):170-177

Lawrance D.R. and Bacharach A.I. 1964. Evaluation of Drug Ativities: Pharmacometric. New York: Academic Press.

Lu F.C. 1995. Toksikologi Dasar; Asas,Organ Sasaran, dan Penilaian Resiko. Edisi ke2.Penerbit Universitas Indonesia. Jakarta: UI Press.

Marianne P.T., Litiele C., Jeferson L.F., Renara B.V. and Valdir M.S. 2016. Ethnobotany and antioxidant evaluation of commercialized medicinal plants from the Brazilian Pampa. Acta Botanica Brasilica 30(1):47-59.

Niranjan R. 2016. Liver. Journal of Liver. 5 (3). DOI: 10.4172/2167-0889.1000e112.

Ozougwu J. 2017. Physiology of the liver. International Journal of Research in Pharmacy and Biosciences. 4(8):13-24.

Robbins S.L., Cotran R.S. dan Kumar V. 2007. Jejas Adaptasi dan Kematian Sel. Dalam: Buku Ajar Patologi I. Jakarta: EGC.
Sujono T.A., Arifah S.R. Muhammad D., Ika T.D.K., Andi S., Rima M., Nanik P., Saidatul F., Riya R. dan Siti L. 2015. Pengaruh pemberian ekstrak etanol meniran (phyllanthus niruri 1) selama 90 hari terhadap fungsi hati tikus. University Research Colloquium. 136-142

Tatukude P., Lily L. dan Poppy L. 2014.Gambaran histopatologi hati mencit swiss yang diberi air rebusan sarang semut (Mymercodia pendans) paska induksi dengan carbon tetrachlorida ( $\left.\mathrm{CCL}_{4}\right)$. Jurnal e-Biomedik (Ebm). 2(2):459-466.

Westbrook R.H., Dusheiko G. and Williamson. 2016. Pregnancy and Liver Disease. Journal of Hepatology. 64:933-945.

Wicaksono H.S., Inna N. dan Iriani S. 2015.Struktur hati mencit (Mus musculus 1.) Setelah pemberian ekstrak daun kaliandra merah (Calliandra calothyrsus meissn) Jurnal simbiosis III. (1):258268. 